provision made for this class of case must feel a sense of shame that as yet nothing has been done for them in Fngland. I refer, of course, to the nursling hospitals of Paris, Berlin, and Vienna, with their army of wet-nurses. The results obtained at these institutions are little short of marvellous, and $I$ would recommend any who are interested in this subject to read Professor Budin's book, "The Nursling," translated into English by Dr. W. J. Maloney.

Bradford.

\section{Clintral êtotes:}

MEDICAL, SURGICAL, OBSTETRICAL, AND THERAPEUTICAL.

NOTE ON A CASE OF ADENOIDS ASSOCIATED WITH ALBUMINURIA AND CASTS IN THE URINE :

REMOVAL OF ADENOIDS FOLLOWED BY DISAPPEARANCE OF THE URINARY CHANGES

By J. Morgan O'Meara, M.D., B.S. Lond.

THE patient, a schoolboy, aged 7 years, had always been a delicate boy, continually "catching cold." $\mathrm{He}$ had been attended for two attacks of laryngitis during six weeks, and the question of operation for adenoids was under consideration. Family history: father quite healthy; mother has pronounced nasal obstruction with aural changes.

I was called to see the boy on Feb. 1st last, and was told that he had been very restless during the night and had not heen taking his food for the last day or two. The urine had been very thick and rather scanty. On examination he was somewhat pale and seemed a little drowsy. There was marked nasal obstruction. No odema could be detected, and there were no abnormal physical signs in the chest. There was no hypertrophy of the heart, and the pulse was not of bigh tension ( 60 beats in one minute); the temperature was normal. The urine was turbid and smoky and on standing gave a thick deposit. Its specific gravity was 1014, and the reaction was acid. On boiling and adding acetic acid there was a little albumin precipitated (a 5 -inch column of urine when boiled and allowed to stand 24 hours, gave a deposit of about $\frac{1}{4}$ inch). Microscopical examination of the sediment from the urine showed an enormous number of casts-blood, epithelial, granular, and hyaline-and also renal cells and red blood corpuscles.

The patient was kept in bed and ordered a milk diet. On Feb. 2 nd he was rather brighter; urinary changes were slightly iess marked. On the 4th he was much brighter and said he felt well. Albumin rather less, but very numerous casts (hyaline, granular, and epithelial). On the 8th, the albumin settled to $\frac{1}{8}$ inch on boiling as before; casts very numerous but not quite so many as at first. The patient now got up. He was kept to a diet of milk, milk puddings, \&c., with fruit and bread and butter. By the $13 \mathrm{th}$ the general condition was good, but the urine was almost unchanged. On the $20 \mathrm{th}$ his general condition was still good. The urine showed a trace of albumin, and the casts (hyaline, granular, and epithelial) were still very numerous. There was, perhaps, a tendency towards a greater proportion of hyaline and a smaller proportion of epithelial casts.

By this time I did not think it would be possible to keep the boy indoors much longer. I advised that the adenoids should be removed, as I then thought that these might be aggravating or prolonging the renal condition, and I felt that any fresh "colds" would be likely to be harmful to the kidneys. On Feb. 22nd, therefore, a large mass of adenoids was removed under chloroform. On the 23rd the patient had passed a good night and felt very well. The parents thought that he was better than before the operation and that the urine was clearer. I could not be certain as to any definite changes in the urine, but was inclined to think there were rather fewer epithelial casts. On the 24th the general condition was very good. The lower eyelids looked thin and dark, and this rather suggested to me that there had been slight odema which I was unable to detect. The casts were definitely fewer and there was no albumin. On the 25th there was no albumin ; casts wera few in number and required careful looking for. On the 27 th the urine was of specific gravity 1020 and increased in quantity; no albumin, no casts. On March 2nd the general condition was very good; the urine contained no albumin and no casts. The patient was allowed out of doors. During the next four weeks he remained quite well and has so continued. On March 27 th the urine was clear, specific gravity 1020, no albumin, and no casts.

There were two points that especially struck $m e$ in this case: 1. The association of a very large number of casts with a quite small quantity of albumin. Apart from microscopical examination, the urine might almost have been passed as normal at a time when there were a great many casts. 2. That very marked improvement set in immediately after removal of the adenoids, so that there was more improvement in three days after the operation than in the three weeks preceding it.

Luton.

NOTE ON A CASE OF FOREIGN BODY IN THE ISCHIO-RECTAL FOSSA RETAINED FOR A YEAR AND A HALF.

By Nelly Evans, L.R.C.P.\& S. Edin., SURGEON TO THE VICTORIA ZENANA IIOSPITAL, H.H. THE NIZAM's GOVERXMENT, HYDERABAD.

A WOMAN of about 30 years of age, a Hindoo widow, was admitted to the Victoria Zenana Hospital on Feb. 9th, 1911, complaining of a sinus of six months' duration situated in the right ischio-rectal fossa. It was supposed to be a case of fistula in ano, and accordingly chloroform was administered and a director passed into the sinus. The instrument travelled in an upward direction and, with a finger in the rectum, it could be felt to pass behind the bowel and enter a thickening behind the cervix uteri; at the same time there was a thick blood coloured discharge from the vagina. After washing this away a sound was passed into the cervix and could be felt to come in contact with the director. The opening in the right ischio-rectal fossa was then enlarged and the sinus scraped; almosi at once a dark object presented at the wound. This was found after removal to be a twig $3 \frac{1}{4}$ inches long and a line in diameter, with a small quantity of cotton-wool twisted round one extremity.

The following history was afterwards obtained. A year and a half previously the patient, being three months pregnant, had called in a dhai (native midwife) to procure abortion. The dhai "treated" her and abortion took place, followed by an illness of a couple of months' duration. The sinus had begun a year later as an irritable pimple, and for six months the patient had been troubled by the constant discharge from it, but had not connected this in any way with the abortion.

The native midwife frequently procures abortion by the introduction of twigs or other small bodies into the uterus, but it is not usual for a foreign body to be retained so long after abortion has occurred. It was evident that the twig had been so introduced that the lower end, which was somewhat pointed, had passed into the cervix and thus had been forced through the cervix by the uterine contractions.

The sinus healed quickly and the patient was discharged five days after admission.

Hyderabad.

Evelina Hospital for Sirk Childoren.Viscount Duncannon, at the annual court of governors of this hospital, in submitting the annual report pointed out with gratification that there had been an appreciable decrease in the cost of patients, which testified to the economy and vigilant supervision exercised by the committee of management. In the course of his address he emphasised the pressing needs of the hospital, urging that it is the only large children's hospital for the whole of South London, is situated in its most destitute district, and is carrying on a beneficent and increasing work in relieving suffering amongst children of the poorest class. There had been a heavy loss, he added, in annual subscriptions during the last few years, and he earnestly appealed for new supporters. 